\title{
Penggunaan Jurnal Reflektif pada Pembelajaran Matematika untuk Melatih Kemampuan Komunikasi Matematis Siswa
}

\author{
Aning Wida Yanti ${ }^{*}$, Nabella Ayu Novitasari ${ }^{2}$ \\ 1*Program Studi Pendidikan Matematika, UIN Sunan Ampel \\ Jalan A. Yani No 117, Surabaya, Jawa Timur, Indonesia \\ 1*aning.widayanti@uinsby.ac.id \\ ${ }^{2}$ SD Islam Sabilillah \\ Perumahan Gading Fajar No 2, Sidoarjo, Jawa Timur, Indonesia \\ 2billybella190@gmail.com
}

Artikel diterima: 22-11-2020, direvisi: 21-05-2021, diterbitkan: 31-05-2021

\begin{abstract}
Abstrak
Banyak siswa mengalami kesulitan dalam belajar matematika, namun guru tidak mempunyai banyak informasi, sehingga guru tidak dapat memberikan solusi yang terbaik. Tujuan penelitian ini untuk mendeskripsikan respon siswa, hasil belajar siswa, serta mndeskripsikan kemampuan komunikasi matematis siswa pada pembelajaran matematika dengan menggunakan jurnal reflektif. Metode Penelitian yang digunakan adalah deskriptif dengan pendekatan kualitatif dan kuantitatif dengan subjek siswa kelas VII-E di SMPN 6 Sidoarjo. Instrumen yang digunakan meliputi angket respon siswa, tes hasil belajar, dan wawancara. Analisis data kemampuan komunikasi (tulis, lisan) diperoleh dari skor yang diperoleh masing-masing subjek berdasarkan rubrik komunikasi matematis tulis dan lisan, kemudian ditentukan level kemampuan komunikasi matematis siswa. Berdasarkan hasil dan pembahasan didapat bahwa ketuntasan hasil belajar siswa $75 \%$ (rerata 78,6$)$, respon siswa baik $(3,36)$, kemampuan komunikasi matematis siswa rendah, sedang dan tinggi masing-masing pada tingkat 3,4 dan 5. Penggunaan jurnal reflektif dalam pembelajaran matematika dapat melatih kemampuan komunikasi matematis dan hasil belajar siswa.

Kata Kunci: Jurnal Reflektif, Komunikasi Matematis, Pembelajaran Matematika.
\end{abstract}

\section{Use of Reflective Journals in Mathematics Learning to Train Students' Mathematical Communication Skills}

\begin{abstract}
Many students have difficulty learning mathematics, but the teacher does not have much information, so the teacher cannot provide the best solution. The purpose of this study was to describe student responses, student learning outcomes, and to describe students' mathematical communication skills in mathematics learning using reflective journals. The research method used is descriptive with a qualitative and quantitative approach with the subject of class VII-E students at SMPN 6 Sidoarjo. The instruments used include student response questionnaires, learning outcomes tests, and interviews. Data analysis on communication skills (written, oral) was obtained from the scores obtained by each subject based on written and oral mathematical communication rubrics, then determined the level of students' mathematical communication skills. Based on the results and discussion, it was found that the completeness of student learning outcomes was $75 \%$ (mean 78.6), student responses were good (3.36), students' mathematical communication skills were low, medium, and high at levels 3, 4 and 5 respectively. reflective in mathematics learning can train mathematical communication skills and student learning outcomes.
\end{abstract}

Keywords: Reflective Journal, Mathematical Communication, Mathematics Learning. 


\section{Pendahuluan}

Jurnal reflektif adalah kumpulan pernyataan reflektif siswa tentang pengalaman belajarnya (Kartono \& Imron, 2011; Bashan \& Holsbat, 2017). Dengan demikian jurnal reflektif berpotensi meningkatkan kualitas pembelajaran melalui proses menulis dan berpikir tentang pengalaman belajar, bersifat pribadi dan dapat digunakan untuk merefleksi diri. Jurnal Reflektif merupakan catatan yang digunakan oleh para siswa untuk menuangkan pendapat atau pengalaman mereka tentang proses belajar suatu topik tertentu (Bruno \& Dell'Aversana, 2017). Sebagai contoh: "Minggu ini saya belajar tentang SPLDV. Sulit sekali. Saya benar-benar tidak ngerti bagaimana sih SPLDV. Saya hanya tahu kata bu guru pokoknya menggambar grafik, suku, variabel, koefisien, konstanta, dll. Tapi metode penyelesaiannya juga berbeda-beda. Bu guru sudah menerangkan tapi saya tetep ndak ngerti karena beliau bicara terlalu cepat sekali. Yang diterangkan banyak lagi. Bingung ah. Saya akan minta bu guru menerangkan lagi lebih dalam. Saya juga akan minta contoh dan cara dapat penyelesaiannya dari mana" (Dedy, 2015).

Komponen yang harus termuat dalam sebuah jurnal reflektif adalah: (1) Deskripsi, (2) Rasa dan pikiran, (3) Evaluasi, (4) Analisis, (5) Kesimpulan, (6) Rencana ke depan (Chi \& VanLehn, 2010). Manfaat jurnal reflektif bagi guru adalah: (1) Bahan reflektif untuk pembelajaran ke depan; (2) Bahan untuk membuat tulisan ilmiah; (3) Bahan renungan ketercapaian pembelajaran. Sedangkan manfaat bagi siswa adalah: (1) media untuk pengembangan kreatifitas menulis dan berpikir; (2) Sarana melatih kecakapan emosional siswa; (3) sebagai kegiatan belajar yang positif; (4) sebagai sarana ekspresi jiwa siswa (Suprananto \& Kusaeri, 2012).

Jurnal reflektif membantu guru dalam menemukan kesulitan yang dialami siswa pada saat pembelajaran (Nugroho dkk., 2017). Adapun cara yang digunakan guru untuk menyampaikan pesan dapat secara lisan ataupun tulisan kepada siswa sehingga komunikasi dapat berjalan dengan lancar dan siswa dapat memiliki kemampuan komunikasi matematika dengan baik (Asikin \& Junaedi, 2013; Dewi \& Afriansyah, 2018; Rismen, Mardiyah, \& Puspita, 2020).

Pentingnya kemampuan komunikasi matematis yang dikemukakan oleh Baroody (Hodiyanto, 2017; Nuraeni, 2018) yaitu matematika merupakan alat yang tidak ternilai untuk mengkomunikasikan berbagai ide dengan jelas, tepat, dan ringkas tapi jelas, serta merupakan aktivitas sosial yang melibatkan interaksi antara siswa dengan siswa, dan guru dengan siswa. Adapun indikator komunikasi matematis dalam pembelajaran matematika menurut NCTM tahun 2000 (Husna, Ikhsan, \& Fatimah, 2013; Robiana \& Handoko, 2020) sebagai berikut (1) mampu mengekspresikan melalui lisan, tulisan, dan memvisualisasikan konsep matematika; (2) mampu memahami, menginterpretasikan, dan mengevaluasi ide-ide matematis baik secara lisan, tulisan, maupun dalam bentuk visual lainnya; (3) mampu menggunakan istilah- 
istilah, notasi-notasi matematika dan struktur-strukturnya untuk menyajikan ideide serta menggambarkan hubungan antar konsep matematika.

Peran guru di sekolah sangat dibutuhkan dalam tercapainya tujuan pembelajaran matematika (Acharya, 2017; Rahayu \& Afriansyah, 2021), akan tetapi siswa merasa kesulitan dalam mempelajari matematika ketika mengkaitkan antar konsep-konsep matematika. Pada sebuah proses pembelajaran, bila siswa diminta untuk menggambarkan secara tertulis pengalaman belajar yang telah didapatkan, siswa akan terdorong untuk menyadari apa yang mereka alami dan mampu mengungkapkannya secara tertulis (Heggart \& Yoo, 2018). Teknik yang banyak digunakan dalam hal ini adalah jurnal reflektif, yakni sebuah catatan reflektif yang dibuat dari hari ke hari (Warsono \& Hariyanto, 2012).

Berdasarkan hasil analisis peneliti saat melakukan data observasi awal di SMPN 6 Sidoarjo melalui wawancara dengan beberapa guru, diperoleh bahwa kemampuan komunikasi matematis siswa masih kurang. Siswa mengalami kesulitan dalam mengomunikasikan ide matematika secara jelas dan benar melalui lisan maupun tulisan. Dari hasil ini tentunya dengan diberikan jurnal reflektif siswa dapat menuangkan idenya dalam bentuk tulisan maupun lisan sehingga guru memiliki informasi yang cukup untuk membantu kesulitan siswa dalam belajar.

Terdapat beberapa penelitian terkait jurnal reflektif (Munawaroh dkk., 2016; Faizin, 2018) pada penelitian tersebut hanya mengukur kemampuan komunikasi matematis tulis menggunakan metode tes kemampuan awal dan akhir. Sedangkan pada penelitian ini untuk mengetahui tingkat kemampuan komunikasi lisan siswa, serta menggunakan tes hasil belajar matematika untuk memperoleh data hasil belajar siswa selama proses pembelajaran dan untuk mengetahui tingkat kemampuan komunikasi matematis tulis siswa dan juga menggunakan pedoman wawancara untuk mengetahui tingkat kemampuan komunikasi lisan siswa. Sedangkan penelitian yang dilakukan oleh Setyadi \& Saefudin (2019) merupakan penelitian pengembangan modul matematika berbasis masalah, hanya menguji tingkat kepraktisan dari jurnal reflektif saja. Sedangkan pada penelitian ini menggunakan penelitian deskriptif kualitatif dan kuantitatif bertujuan mendeskripsikan keefektifan jurnal reflektif untuk melatih kemampuan komunikasi matematis siswa pada materi Aljabar kelas VII. Temuan pada penelitian ini menyatakan bahwa respon siswa terhadap pembelajaran baik, hal ini menunjukkan bahwa jurnal reflektif memiliki keefektifan baik dalam pembelajaran matematika. Hasil belajar siswa pun sangat baik, dan kemampuan komunikasi matematis siswa pun baik walaupun untuk siswa yang berkemampuan rendah harus ditingkatkan lagi.

Bila dibandingkan dengan hasil penelitian sebelumnya, yaitu dengan penelitian yang dilakukan oleh Faizin (2018) dan Munawaroh dkk. (2016) dapat dilihat bahwa pembelajaran matematika dengan jurnal reflektif lebih efektif digunakan dalam pembelajaran. Maka dari itu 
diharapkan hasil dari penelitian ini dapat menjadi sumber referensi bagi guru dalam menciptakan pembelajaran yang diharapkan, sehingga tujuan dalam pembelajaran dapat tercapai. Yang lebih harus diperhatikan bagaimana kita mengemas pembelajaran yang bisa memfasilitasi peningkatan kemampuan matematis bagi siswa yang berkemampuan rendah (Rittle-Johnson, Zippert, \& Boice, 2019). Karena dengan guru menerapkan pembelajaran yang menekankan pada keaktifan siswa dan memberikan kesempatan pada siswa untuk mengembangkan potensinya secara maksimal itu dapat memfasilitasi siswa dalam mengahadapi masalah dalam pembelajaran matematika (Putra, 2016; Simamora \& Saragih, 2019).

Tujuan penelitian ini adalah: (1) Mendeskripsikan respon siswa terhadap jurnal reflektif pada pembelajaran matematika, (2) Mendeskripsikan hasil belajar siswa pada pembelajaran matematika dengan menggunakan jurnal reflektif, (3) Mendeskripsikan kemampuan komunikasi matematis siswa setelah pembelajaran menggunakan jurnal reflektif.

\section{Metode}

Penelitian yang digunakan adalah penelitian deskriptif dengan menggunakan pendekatan kualitatif dan kuantitatif (Moleong, 2019). Penelitian ini dilaksanakan di SMPN 6 sidoarjo di kelas VII-E berjumlah 33 siswa untuk mengisi jurnal reflektif, mengerjakan tes hasil belajar dan mengisi angket respon siswa. Angket respon siswa tersebut terdiri dari 15 nomor item, lembar jurnal reflektif yang terdiri dari 6 soal uraian, dan tes hasil belajar yang terdiri dari 2 soal uraian. Teknik pengumpulan data yang digunakan adalah angket, tes hasil belajar, dan wawancara. Teknik angket digunakan untuk memperoleh data respon siswa dan penilaian jurnal reflektif. Sedangkan untuk Tes Hasil Belajar digunakan untuk memperoleh data hasil belajar siswa berupa tes subjektif (2 soal uraian). Selanjutnya dipilih 6 subjek penelitian berdasarkan kemampuan komunikasi matematisnya terdiri dari 2 subjek yang mempunyai kemampuan komunikasi matematis tinggi, 2 sedang, dan 2 rendah. Pengambilan subjek juga berdasarkan pertimbangan guru bidang studi matematika. Sedangkan Wawancara dilakukan dengan wawancara berbasis tugas berisi pertanyaaan-pertanyaan mengenai aktivitas subjek dalam memecahkan masalah Aljabar.

Instrumen yang digunakan dalam penelitian ini terdiri dari: (1) instrumen primer yaitu peneliti peneliti sebagai pewawancara (interviewer), dan (2) instrumen sekunder yaitu: (a) Lembar Angket dan (b) Pedoman wawancara. Analisis data yang dilakukan peneliti antara lain sebagai berikut: (1) Respon Siswa untuk melihat respon siswa terhadap penggunaan Jurnal Reflektif; (2) Tes Hasil Belajar, digunakan untuk mendeskripsikan ketuntasan hasil belajar siswa berdasarkan standar ketuntasan minimal (SKM) di sekolah tempat penelitian berlangsung (Astriani, 2017); (3) Kemampuan Komunikasi Matematis Tulis dan Lisan untuk melihat gambaran atau deskripsi hasil kemampuan komunikasi matematis siswa. Berdasarkan hasil skor tersebut, 
dapat ditentukan level kemampuan komunikasi matematis siswa secara tulis. Analisis data kemampuan komunikasi lisan dilakukan dengan memperhatikan skor yang diperoleh masing-masing subjek. Sehingga dapat ditentukan level kemampuan komunikasi matematis siswa secara lisan melalui wawancara (Liawati \& Wijayanti, 2020).

Sebelum penelitian dilaksananakan, peneliti melakukan uji instrumen tes matematika hasil pembelajaran yang digunakan untuk mengetahui hasil belajar siswa. Uji instrumen atau biasa disebut validasi ini untuk menguji kesahihan instrumen tersebut (Idrus, 2009; Bariah, 2019). Prosedur penelitian yang digunakan dalam penelitian ini terdiri dari empat tahap, yaitu: (1) Tahap Persiapan, (2) Tahap Pelaksanaan, (3) Tahap Analisis Data dan (4) Tahap Penyusunan Laporan Penelitian.

\section{Hasil dan Pembahasan}

\section{A. Hasil}

1) Respon Siswa

Data respon siswa didapatkan melalui lembar angket. Lembar angket tersebut berisikan aspek pertanyaan yang telah disesuaikan dengan masalah penelitian guna dapat mengungkap tanggapan siswa selama mengikuti proses pembelajaran dengan menggunakan jurnal reflektif. Selain berisikan aspek pertanyaan, angket respon berisikan kolom jawaban sangat setuju, setuju, cukup setuju, dan tidak setuju. Terdapat 15 butir pernyataan yang harus diisi oleh peserta didik dan 6 butir pertanyaan dalam jurnal reflektif untuk melatih kemampuan komunikasi matematis siswa pada materi aljabar. Teknis pemberian angket respon adalah diberikannya setelah akhir diterapkan proses pembelajaran. Hasil respon siswa merupakan ungkapan siswa selama mengikuti dan melaksanakan jurnal reflektif, hasil tersebut dapat dilihat pada Tabel 1 sebagai berikut:

Tabel 1.

Respon Siswa terhadap Jurnal Reflektif

\begin{tabular}{|c|c|c|c|}
\hline No & Item yang Dinilai & $\begin{array}{c}\text { Rata- } \\
\text { rata }\end{array}$ & Kriteria \\
\hline 1 & $\begin{array}{l}\text { Guru menyampaikan isi } \\
\text { jurnal dengan jelas }\end{array}$ & 3,75 & $\begin{array}{c}\text { Sangat } \\
\text { Baik }\end{array}$ \\
\hline 2 & $\begin{array}{l}\text { Saya senang mengikuti } \\
\text { pembelajaran } \\
\text { matematika dengan } \\
\text { jurnal reflektif }\end{array}$ & 3,30 & Baik \\
\hline 3 & $\begin{array}{l}\text { Dengan jurnal reflektif, } \\
\text { saya merasa } \\
\text { bersemangat untuk } \\
\text { belajar matematika }\end{array}$ & 3,27 & Baik \\
\hline 4 & $\begin{array}{lr}\text { Jurnal } & \text { reflektif } \\
\text { membantu } & \text { saya fokus } \\
\text { dalam } & \text { belajar } \\
\text { matematika } & \\
\end{array}$ & 3,21 & Baik \\
\hline 5 & $\begin{array}{l}\text { Dengan adanya jurnal } \\
\text { reflektif, saya dapat } \\
\text { mengingat kembali } \\
\text { materi pembelajaran } \\
\text { yang telah dipelajari }\end{array}$ & 3,24 & Baik \\
\hline 6 & $\begin{array}{l}\text { Jurnal Reflektif yang } \\
\text { digunakan } \\
\text { mempermudah dalam } \\
\text { memahami materi }\end{array}$ & 3,66 & $\begin{array}{c}\text { Sangat } \\
\text { Baik }\end{array}$ \\
\hline 7 & $\begin{array}{l}\text { Jurnal reflektif dapat } \\
\text { menunjukkan } \\
\text { sejauhmana tingkat } \\
\text { penguasaan materi saya }\end{array}$ & 3,51 & $\begin{array}{c}\text { Sangat } \\
\text { Baik }\end{array}$ \\
\hline 8 & $\begin{array}{l}\text { Isi yang ada dalam } \\
\text { jurnal membuat saya } \\
\text { berpikir kritis mengenai } \\
\text { materi yang telah } \\
\text { dipelajari }\end{array}$ & 3,33 & Baik \\
\hline 9 & $\begin{array}{l}\text { Dengan jurnal reflektif, } \\
\text { saya faham dengan } \\
\text { materi aljabar }\end{array}$ & 3,48 & $\begin{array}{c}\text { Sangat } \\
\text { Baik }\end{array}$ \\
\hline 10 & $\begin{array}{lr}\text { Jurnal } & \text { reflektif } \\
\text { membantu } & \text { saya } \\
\text { mengevaluasi } & \\
\text { pembelajaran } & \text { dan } \\
\text { langkah-langkah } & \text { untuk } \\
\text { mengatasinya } & \\
\end{array}$ & 3,45 & $\begin{array}{c}\text { Sangat } \\
\text { Baik }\end{array}$ \\
\hline
\end{tabular}




\begin{tabular}{|c|c|c|c|}
\hline 11 & $\begin{array}{l}\text { Jurnal reflektif dapat } \\
\text { memotivasi saya untuk } \\
\text { giat belajar }\end{array}$ & 3,54 & $\begin{array}{c}\text { Sangat } \\
\text { Baik }\end{array}$ \\
\hline 12 & $\begin{array}{l}\text { Dengan Jurnal Reflektif, } \\
\text { saya dapat menemukan } \\
\text { dan menyelesaikan } \\
\text { masalah matematika } \\
\text { sendiri }\end{array}$ & 3,06 & Baik \\
\hline 13 & $\begin{array}{lr}\text { Jurnal } & \text { Reflektif } \\
\text { membantu } & \text { saya } \\
\text { meningkatkan } & \\
\text { kebiasaan belajar } & \\
\end{array}$ & 3,39 & Baik \\
\hline 14 & $\begin{array}{l}\text { Dengan menggunakan } \\
\text { Jurnal Reflektif, saya } \\
\text { menjadi lebih aktif } \\
\text { dalam belajar } \\
\text { matematika }\end{array}$ & 3,39 & Baik \\
\hline 15 & $\begin{array}{l}\text { Dengan Jurnal Reflektif } \\
\text { saya dapat memberi } \\
\text { kesimpulan dari materi } \\
\text { yang telah diajarkan }\end{array}$ & 3,21 & Baik \\
\hline & Total Rata-rata & 3,36 & Baik \\
\hline
\end{tabular}

Berdasarkan analisis data dapat diketahui total rata-rata yang diperoleh dari data hasil respon siswa adalah 3,36. Jadi kriteria keefektifan yang dicapai jurnal reflektif tersebut termasuk kriteria "baik". Sehingga dapat dikatakan bahwa jurnal reflektif yang digunakan memiliki derajat keefektifan yang baik. Hasil data penilaian jurnal reflektif yang telah diisi oleh siswa kelas VII-E sebanyak 33 orang siswa secara singkat disajikan dalam Tabel 2 sebagai berikut:

Tabel 2.

Persentase Penilaian Jurnal Reflektif

\begin{tabular}{lccc}
\hline No & Kategori & $\begin{array}{c}\text { Jumlah } \\
\text { Siswa }\end{array}$ & Persentase \\
\hline 1 & Tinggi & 16 & $53,3 \%$ \\
\hline 2 & Sedang & 15 & $45 \%$ \\
\hline 3 & Rendah & 2 & $1,7 \%$ \\
\hline
\end{tabular}

Berdasarkan analisis data respon siswa selama menggunakan jurnal reflektif dalam pembelajaran matematika yang diberikan di akhir pertemuan diperoleh kesimpulan bahwa respon siswa terhadap penggunaan jurnal reflektif adalah respon positif
(Respon dikatakan positif jika peserta didik merespon minimal dalam kategori sedang) dengan minimal persentase kategori sedang yaitu $45 \%$.

2) Hasil Belajar

Berikut tes soal yang diberikan kepada siswa untuk memperoleh data hasil belajar siswa selama proses pembelajaran dan untuk mengetahui kemampuan komunikasi matematis tulis siswa. Tes soal ini diberikan kepada siswa setelah siswa mengisi angket respon siswa terhadap jurnal reflektif dan lembar penilaian jurnal reflektif.

1. Pada hari Minggu Rina pergi ke supermarket bersama ibunya, Rina membeli 6 buku dan 3 pensil. Sesampainya di rumah, Rina memberikan 4 buku dan 2 pensil miliknya kepada adiknya, kemudian pada hari selasa Rina pergi lagi untuk membeli 6 buku dan 4 pensil yang sama dengan buku dan pensil yang ia beli pada hari minggu. Buatlah permodelan matematika berbentuk Aljabar! Berapa banyak buku dan pensil yang dimiliki Rina?

2. Pak Irfan memiliki sebidang tanah berbentuk persegi dengan sisi-sisinya $(10-x)$ meter. Di tanah tersebut ia akan membuat kolam ikan berbentuk persegi dengan sisi-sisinya $(8-x)$ meter. Jika ia menyisakan tanah itu seluas $28 \mathrm{~m} 2$, berapakah luas tanah pak Irfan sebenarnya?

Berdasarkan analisis data hasil belajar siswa setelah proses pembelajaran dengan menggunakan jurnal reflektif pada materi Aljabar siswa kelas VII-E SMPN 6 Sidoarjo dapat dilihat bahwa siswa yang tuntas sebanyak 25 siswa dengan persentase $75 \%$ dan siswa yang tidak tuntas sebanyak 8 
siswa dengan persentase sebesar 25\%. Hal tersebut berarti bahwa banyak siswa yang tuntas lebih banyak dibandingkan dengan banyak siswa yang tidak tuntas dalam mengerjakan soal tes kemampuan komunikasi matematis. Untuk rata-rata nilai seluruh siswa yaitu 78,6 yang termasuk dalam kategori sangat tinggi.

3) Kemampuan Komunikasi Matematis

a) Subjek dengan kemampuan komunikasi matematis tinggi

Subjek dengan kemampuan komunikasi matematis tinggi menunjukkan telah mampu melaksanakan proses penyelesaian masalah dengan jelas dan benar, yaitu menulis apa yang diketahui dari soal, menuliskan pemisalan, menuliskan perhitungan dan juga menuliskan kesimpulan. Hal ini menunjukkan bahwa siswa yang memiliki kemampuan komunikasi tinggi mampu mendapatkan informasi data yang dapat membantunya seperti pemahaman pada permisalan variabel.

Subjek dengan kemampuan komunikasi matematis tinggi mampu menjawab pertanyaan saat melakukan wawancara. Selain itu, siswa dengan kemampuan komunikasi tinggi juga memberikan respon dan argumen yang aktif saat berkomunikasi, juga dapat mengucapkan langkah-langkah perhitungannya dengan terstruktur dan jelas serta mampu menjelaskan dasar teori yang digunakan saat ditanya alasan.

Subjek dengan kemampuan komunikasi matematis tinggi dalam menyelesaikan masalah Aljabar memiliki kemampuan komunikasi matematis tulis pada tingkat 5. Sedangkan siswa dengan kemampuan komunikasi tinggi memiliki kemampuan komunikasi matematis lisan pada tingkat 5.

b) Subjek dengan kemampuan komunikasi matematis sedang

Subjek dengan kemampuan komunikasi matematis sedang melakukan proses penyelesaian seperti yang dilakukan siswa yang memiliki kemampuan komunikasi tinggi, namun tidak menuliskan pemisalan pada lembar jawabannya. Siswa yang memiliki kemampuan komunikasi matematis sedang mampu memahami masalah dengan mengungkapannya menggunakan kalimatnya sendiri terlihat saat ia menuliskan kesimpulan dari pekerjaannya serta melakukan kesalahan-kesalahan kecil dalam melakukan perhitungan dan penggunaan simbol matematika.

Subjek dengan kemampuan komunikasi matematis sedang mampu menjawab pertanyaan-pertanyaan dari panduan wawancara yang diberikan oleh peneliti. Siswa ini juga mampu memberikan respon dan argumen. Namun ia masih sering melakukan kesalahan dalam menjelaskan langkah perhitungannya. Hal ini juga mempengaruhi struktur penjelasan yang ia berikan dan juga masih ragu-ragu dalam menjelaskan strategi yang ia gunakan untuk mencari solusi.

Subjek dengan kemampuan komunikasi matematis sedang dalam menyelesaikan masalah Aljabar memiliki kemampuan komunikasi matematis tulis 
pada tingkat 4 dengan soal yang berbeda. Selanjutnya siswa berkemampuan komunikasi sedang memiliki kemampuan komunikasi matematis lisan pada tingkat 4.

c) Subjek dengan kemampuan komunikasi rendah

Sementara itu subjek dengan kemampuan komunikasi matematis rendah tidak menuliskan proses penyelesaian masalah dengan benar, tidak menuliskan apa yang diketahui dari soal dan tidak melakukan permisalan. Siswa dengan kemampuan komunikasi matematis rendah juga masih salah dalam mengubah masalah ke kalimat matematika dan masih belum bisa mengubah kembali hasil perhitungannya ke penarikan kesimpulan serta melakukan kesalahan dalam perhitungannya. Hal ini dikarenakan kesalahan dalam penggunaan simbol matematika. Dalam hal ini, siswa yang memiliki kemampuan komunikasi matematis rendah belum mampu menyadari komunikasi verbal yang dimunculkan dalam suatu masalah.

Sedangkan dalam kemampuan komunikasi matematis lisannya, subjek dengan kemampuan komunikasi matematis rendah belum mampu menjawab pertanyaan-pertanyaan yang diberikan peneliti pada pedoman wawancara dan menolak memberikan pertanyaan saat berkomunikasi serta tidak memberikan solusi dan argumen. Siswa dengan kemampuan komunikasi matematis rendah juga masih melakukan kesalahan dalam mengucapkan langkah-langkah perhitungan yang diperlukan dan ragu- ragu dalam menjelaskan penyelesaian masalah. Berdasarkan hal tersebut, siswa dengan kemampuan komunikasi matematis rendah belum memiliki keterampilan berbicara secara efektif.

Subjek dengan kemampuan komunikasi matematis rendah dalam menyelesaikan masalah Aljabar memiliki kemampuan komunikasi matematis tulis pada tingkat 3. Sedangkan siswa dengan kemampuan komunikasi rendah memiliki kemampuan komunikasi matematis lisan pada tingkat 3.

\section{B. Pembahasan}

\section{1) Respon Siswa}

Berdasarkan 15 aspek yang ditanyakan terkait respon siswa terdapat dua aspek yang memiliki rata-rata 3,75 dan 3,66 dengan kategori sangat baik. Kedua aspek tersebut adalah guru menyampaikan isi jurnal dengan jelas dan jurnal reflektif yang digunakan mempermudah dalam memahami materi. Artinya secara umum, siswa tertarik apabila refleksi pada akhir proses pembelajaran menggunakan jurnal reflektif, karena siswa lebih senang menyimpulkan materi pembelajaran dalam bentuk tulisan daripada dengan lisan. Dalam jurnal reflektif yang digunakan, siswa dapat mengetahui bagian-bagian mana saja yang sudah dipahami maupun yang belum dipahami, dengan jurnal reflektif siswa dapat mengungkapkan masalah ataupun kesulitan yang dihadapi selama proses pembelajaran dan dapat mengetahui cara untuk mengatasi kesulitan tersebut, dan dengan jurnal reflektif siswa dapat menuliskan harapan-harapan kepada guru untuk pembelajaran selanjutnya. Hal ini sesuai dengan Munawaroh dkk. (2016) dan Primayanti Suwu, \& Appulembang 
(2018) bahwa respon siswa terhadap jurnal reflektif dapat melatih kemampuan komunikasi matematisnya.

2) Hasil Belajar

Berdasarkan hasil analisis data diperoleh bahwa dari 33 Siswa Kelas VII-E SMPN 6 Sidoarjo yang mendapatkan nilai $\geq 75$ adalah sebanyak 25 siswa dari jumlah seluruh siswa dan 8 siswa yang $<75$. Sehingga persentase ketuntasan kelas sebesar $75 \%$. Jadi kriteria keefektifan yang dicapai jurnal reflektif tersebut termasuk kriteria "baik" karena 25 siswa dikategorikan "tuntas belajar" dengan skor rata-rata hasil belajar seluruh siswa di kelas adalah 78,6 atau memperoleh nilai $\geq 75$. Berdasarkan analisis data tersebut siswa kelas VII-E SMPN 6 Sidoarjo telah memahami materi yang disajikan dengan menggunakan jurnal reflektif. Hal ini sesuai dengan Setyadi \& Saefudin (2019) dan Pitriani, Rohana, \& Ningsih (2019) bahwa hasil belajar setelah pembelajaran menggunakan jurnal reflektif dapat melatih kemampuan komunikasi matematisnya.

3) Kemampuan Komunikasi Matematis

Siswa kelas VII-E yang memiliki kemampuan komunikasi tinggi telah mampu mengkomunikasikan secara tulis dan lisan aktivitas dalam menyelesaikan masalah Aljabar. Hal tersebut disebabkan siswa yang yang memiliki kemampuan komunikasi tinggi mampu menjalin komunikasi verbal dan nonverbal yang efektif dengan orang lain. Hal ini sesuai dengan Putra \& Patmaningrum (2018) dan Liawati \& Wijayanti (2020).

Siswa kelas VII-E yang memiliki kemampuan komunikasi matematis sedang telah mampu mengomunikasikan secara tulis dan lisan hasil penyelesaian masalah Aljabar. Siswa yang memiliki kemampuan komunikasi matematis sedang belum mampu melakukan perhitungan dan menggunakan simbol dengan tepat. Hal ini menunjukkan bahwa siswa dengan kemampuan komunikasi matematis sedang memiliki kemampuan komunikasi matematis lisan yang lebih dominan daripada komunikasi matematis tulisnya. Hal ini sesuai dengan Liawati \& Wijayanti (2020) dan Marfiah \& Pujiastuti (2020).

Siswa dengan kemampuan komunikasi matematis rendah juga masih melakukan kesalahan dalam mengucapkan langkahlangkah perhitungan yang diperlukan dan ragu-ragu dalam menjelaskan penyelesaian masalah. Berdasarkan hal tersebut, siswa dengan kemampuan komunikasi matematis rendah belum memiliki keterampilan berbicara secara efektif. Hal ini sesuai dengan Kumalaretna \& Mulyono (2017) dan Liawati \& Wijayanti (2020).

\section{Penutup}

Berdasarkan hasil penelitian dan pembahasan maka keefektifan jurnal reflektif untuk melatih kemampuan komunikasi matematis siswa pada pembelajaran matematika dilihat berdasarkan 3 aspek yaitu: (1) Respon siswa, data hasil respon siswa dengan kriteria "baik", sehingga dapat dikatakan bahwa jurnal reflektif yang digunakan memiliki derajat keefektifan yang baik; (2) Hasil Belajar, hasil belajar siswa pada pembelajaran matematika dengan menggunakan jurnal reflektif diperoleh persentase ketuntasan kelas sebesar 75\%, sehingga kriteria keefektifan yang dicapai 
jurnal reflektif dikatakan "baik" dengan skor rata-rata hasil belajar seluruh siswa di kelas adalah 78,6 sehingga siswa telah memahami materi yang disajikan dengan menggunakan jurnal reflektif;

Kemampuan Komunikasi Matematis tulis dan lisan yaitu (a) Subjek dengan kemampuan komunikasi matematis tinggi dalam menyelesaikan masalah Aljabar memiliki kemampuan komunikasi matematis pada tingkat 5, (b) Subjek dengan kemampuan komunikasi matematis sedang dalam menyelesaikan masalah Aljabar memiliki kemampuan komunikasi matematis tulis pada tingkat 4, (c) Subjek dengan kemampuan komunikasi matematis rendah dalam menyelesaikan masalah Aljabar memiliki kemampuan komunikasi matematis pada tingkat 3 .

Berdasarkan hasil penelitian yang penulis peroleh, maka penulis mengemukakan saran-saran sebagai berikut: (1) Bagi guru, hendaknya memperhatikan perbedaan kemampuan komunikasi matematis yang dimiliki siswa; (2) Kajian penelitian ini masih terbatas pada penggunaan jurnal reflektif untuk melatih kemampuan komunikasi matematis siswa pada pembelajaran matematika pada materi Aljabar, untuk peneliti lain dapat melihat dari tinjauan yang berbeda.

\section{DAfTAR PUstaka}

Acharya, B. R. (2017). Factors affecting difficulties in learning mathematics by mathematics learners. International Journal of Elementary Education, 6(2), 8-15.

Asikin, M., \& Junaedi, I. (2013). Kemampuan Komunikasi Matematika Siswa SMP dalam Setting Pembelajaran
RME (Realistic Mathematics

Education). Unnes Journal of Mathematics Education Research, 2(1), 203-213.

Astriani, L. (2017). Pengaruh Pembelajaran Reciprocal Teaching terhadap Kemampuan Pemahaman Konsep Matematika Ditinjau dari Kemampuan Awal Matematika Siswa. FIBONACCI: Jurnal Pendidikan Matematika Dan Matematika, 3(1), 77-85.

Bariah, S. K. (2019). Rancangan Pengembangan Instrumen Penilaian Pembelajaran Berbasis Daring. Jurnal Petik, 5(1), 31-47.

Bashan, B., \& Holsblat, R. (2017). Reflective journals as a research tool: The case of student teachers' development of teamwork. Cogent Education, 4(1), 1374234.

Bruno, A., \& Dell'Aversana, G. (2017). Reflective practice for psychology students: The use of reflective journal feedback in higher education. Psychology Learning \& Teaching, 16(2), 248-260.

Chi, M., \& VanLehn, K. (2010). Metacognitive Strategy Instruction in Intelligent Tutoring Systems: How, when, and why. Educational Technology and Society, 13(1), 25-39.

Dedy, H. (2015). Pengajaran Profesional dan Pembelajaran Bermakna. Jakarta: USAID DBEJ.

Dewi, S. S. S., \& Afriansyah, E. A. (2018). Kemampuan Komunikasi Matematis Siswa Melalui Pembelajaran CTL. JIPMat, 3(2), 145-155.

Faizin, K. (2018). Pemanfaatan Jurnal Refleksi sebagai Strategi Metakognitif dalam Meningkatkan Keaktifan dan 
Hasil Belajar Matematika. Lentera Pendidikan: Jurnal Ilmu Tarbiyah Dan Keguruan, 21(1), 33-47.

Heggart, K. R., \& Yoo, J. (2018). Getting the most from google classroom: A pedagogical framework for tertiary educators. Australian Journal of Teacher Education, 43(3), 9.

Hodiyanto, H. (2017). Kemampuan komunikasi matematis dalam pembelajaran matematika.

AdMathEdu, 7(1), 9-18.

Husna, Ikhsan, M., \& Fatimah, S. (2013).

Peningkatan Kemampuan Pemecahan

Masalah dan Komunikasi Matematis

Siswa Sekolah Menengah Pertama melalui Model Pembelajaran Koooperatif Tipe Think-Pair-Share (TPS). Jurnal Peluang, 1(2), 81-92.

Idrus, M. (2009). Metode Penelitian IImu Sosial, Pendekatan Kualitatif dan Kuantitatif . Jakarta: Erlangga.

Kartono, \& Imron, A. (2011). Penerapan

Teknik Penilaian Learning Journal pada Model Pembelajaran Berbasis Masalah untuk Meningkatkan Hasil Belajar Siswa Materi Pokok Segiempat. Kreano: Jurnal Matematika KreatifInovatif, 2(1), 57-71.

Kumalaretna, W. N. D., \& Mulyono, M. (2017). Kemampuan Komunikasi Matematis Ditinjau dari Karakter Kolaborasi dalam Pembelajaran Project Based Learning (Pjbl). Unnes Journal of Mathematics Education Research, 6(2), 195-205.

Liawati, R., \& Wijayanti, P. (2020). Profil Komunikasi Matematis Siswa SMP dalam Menyelesaikan Soal Matematika
Ditinjau dari Self Efficacy. MATHEdunesa, 9(2), 382-391.

Marfiah, D. Y., \& Pujiastuti, H. (2020). Analisis Pengaruh Kecerdasan Intrapersonal Terhadap Kemampuan Komunikasi Matematis Siswa Pada Materi Bentuk Aljabar. Al Khawarizmi: Jurnal Pendidikan dan Pembelajaran Matematika, 4(1), 1-15.

Moleong, L. J. (2019). Metodologi Penelitian Kualitatif (Edisi Revisi). Bandung : Remaja Rosdakarya.

Munawaroh, L., Pantiwati, Y., \& Rofieq, A. (2016). Penggunaan Jurnal Belajar dalam Pembelajaran Class Wide Peer Tutoring terhadap Kemampuan Berpikir Kritis Siswa. Jurnal Pendidikan Biologi Indonesia, 1(3), 273-273.

Nugroho, A. A., Putra, R. W. Y., Putra, F. G., \& Syazali, M. (2017). Pengembangan Blog sebagai Media Pembelajaran Matematika. Al-Jabar: Jurnal Pendidikan Matematika, 8(2), 197203.

Nuraeni, R. (2018). Perbandingan Kemampuan Komunikasi Matematis Mahasiswa antara yang Mendapatkan Pembelajaran Group Investigation dengan Konvensional. Mosharafa: Jurnal Pendidikan Matematika, 7(2), 219-228.

Pitriani, E., Rohana, R., \& Ningsih, Y. L. (2019). Peningkatan Kemampuan Komunikasi Matematis Siswa Melalui Pembelajaran Reflektif di SMA. JPPM (Jurnal Penelitian dan Pembelajaran Matematika), 12(1), 142-155.

Primayanti, G., Suwu, S. E., \& Appulembang, O. D. (2018). Penerapan metode drill untuk meningkatkan 
kemampuan komunikasi matematis siswa kelas VIII SMP Lentera Way Pengubuan pada topik persamaan garis lurus [The implementation of the drill method to increase mathematical communication skills of grade 8 students in linear equations topics at SMP Lentera Way Pangubuan]. JOHME: Journal of Holistic Mathematics Education, 1(2), 135-149.

Putra, F. G. (2016). Pengaruh Model Pembelajaran Reflektif dengan Pendekatan Matematika Realistik Bernuansa Keislaman terhadap Kemampuan Komunikasi Matematis. Al-Jabar:Jurnal Pendidikan

Matematika, 7(2), 203-210.

Putra, A., \& Patmaningrum, D. A. (2018). Pengaruh Youtube di Smartphone Terhadap Perkembangan Kemampuan Komunikasi Interpersonal Anak. Jurnal Penelitian Komunikasi, 21(2).

Rahayu, N. S., \& Afriansyah, E. A. (2021).

Miskonsepsi Siswa SMP pada Materi Bangun Datar Segiempat. PLUSMINUS: Jurnal Pendidikan Matematika, 1(1), 17-32.

Rittle-Johnson, B., Zippert, E. L., \& Boice, K. L. (2019). The roles of patterning and spatial skills in early mathematics development. Early Childhood Research Quarterly, 46, 166-178.

Rismen, S., Mardiyah, A., \& Puspita, E. M. (2020). Analisis Kemampuan Penalaran dan Komunikasi Matematis Siswa. Mosharafa: Jurnal Pendidikan Matematika, 9(2), 263-274.

Robiana, A., \& Handoko, H. (2020).

Pengaruh Penerapan Media UnoMath untuk Meningkatkan Kemampuan Komunikasi Matematis dan
Kemandirian Belajar Siswa. Mosharafa: Jurnal Pendidikan Matematika,9(3), 521-532.

Setyadi, A., \& Saefudin, A. A. (2019). Pengembangan Modul matematika dengan Model Pembelajaran Berbasis Masalah untuk Siswa Kelas VII SMP. Pythagoras: Jurnal Pendidikan Matematika, 14(1), 12-22.

Simamora, R. E., \& Saragih, S. (2019). Improving Students' Mathematical Problem-Solving Ability and SelfEfficacy through Guided Discovery Learning in Local Culture Context. International Electronic Journal of Mathematics Education, 14(1), 61-72.

Suprananto, \& Kusaeri. (2012). Pengukuran dan Penilaian Pendidikan. Yogyakarta: Graha Ilmu.

Warsono, \& Hariyanto. (2012). Pembelajaran Aktif: Teori dan Asesme. Bandung: PT. Remaja Rosdakarya.

\section{Riwayat Hidup Penulis}

\section{Aning Wida Yanti, S. Si., M. Pd.}

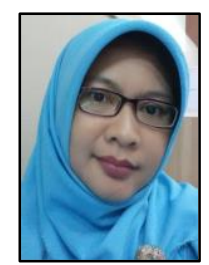

Lahir di Ponorogo, 7 Desember 1980. Staf pengajar di Prodi Pendidikan Matematika UIN Sunan Ampel Surabaya. Studi S1 Matematika UNESA Surabaya, lulus tahun 2003; S2 Pendidikan Matematika UNESA Surabaya, lulus tahun 2006.

\section{Nabella Ayu Novitasari, S. Pd.}

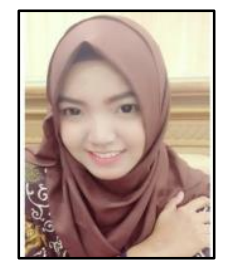

Lahir di Sidoarjo, 3 November 1992. Staf pengajar SD Islam Sabilillah Sidoarjo. Studi S1 Pendidikan Matematika UIN Sunan Ampel Surabaya, Iulus tahun 2019. 